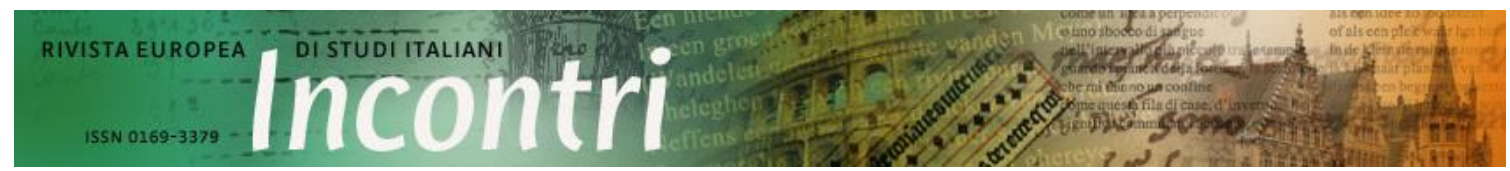

Anno 36, 2021 / Fascicolo 1 / p. 106-109 - www.rivista-incontri.nl - http: //doi.org/10.18352/inc11010

(c) The author(s) - Content is licensed under a Creative Commons Attribution 3.0 Unported License Publisher: Werkgroep Italië Studies, supported by openjournals.nl

\title{
In memoriam Annaserena Ferruzzi
}

\section{Frans Denissen}

Begin december 2020 verscheen op de website van de Amsterdamse uitgeverij Serena Libri, in de rubriek 'Verwacht', een aankondiging van De vorm van water van Andrea Camilleri. Het bericht werd voorafgegaan door de volgende dieptreurige en dieptreurig stemmende 'Noot van de uitgever': 'Deze gereviseerde druk van de eerste Montalbano die ik heb uitgegeven is het 92ste boek dat Serena Libri publiceert en tevens het laatste. Met pijn in mijn hart neem ik afscheid van mijn boeken en van mijn lezers. Drieëntwintig jaar lang heb ik met passie prachtige Italiaanse titels naar Nederland gebracht - werk dat nooit verloren zal gaan.'

Het was allemaal heel snel gegaan. Op 23 november had Annaserena Ferruzzi contact opgenomen met Yond Boeke en Patty Krone, in 1999 de vertaalsters van die vroegste Camilleri, met het bericht dat ze het boek wilde heruitgeven en de vraag of ze na al die jaren misschien de tekst nog eens onder handen wilden nemen. Over haar bedoeling - op deze manier een cirkel rond maken - vertelde ze niets. Op 1 december vroeg ze Hilda Schraa, die voor haar bezig was met de vertaling van Borgo Sud van Donatella di Pietrantonio, het werk daaraan stop te zetten. Ditmaal vermeldde ze wél de reden: een ongeneeslijke ziekte die haar belette nog nieuwe boekprojecten tot een goed einde te brengen.

Kort daarop vertrok ze naar de stad waar ze in 1940 geboren was en bracht daar de kerstdagen met haar geliefden door. Op 5 januari van het nieuwe jaar verscheen in de Volkskrant het bericht:

In Ravenna, Italie, is in familiekring

na een kortstondige ziekte

op 1 januari 2021 overleden

Annaserena Ferruzzi

Onze geliefde Anna,

onze moeilijke Anna,

moeder van Daniel en Simona, oma van Matteo.

Begenadigde gastvrouw en fantasierijke chef,

strenge docente Italiaans aan de Universiteit,

oprichtster van uitgeverij Serena Libri

en onvermoeibare uitgeefster van Italiaanse schrijvers.

Onze onvergetelijke Anna.

(...)

Anna wordt op 8 januari begraven in Ravenna, haar geboorteplaats.

Annaserena - Anna in de omgang - kwam in 1964 naar Amsterdam in het kielzog van haar Nederlandse verloofde, die ze in Ravenna had leren kennen. Ze trouwden er en kregen een dochter en een zoon. Vóór haar vertrek uit Italië had ze in Milaan al Engelse 
taal- en letterkunde gestudeerd, en op haar vierendertigste - tien jaar na haar aankomst in Nederland - besloot ze opnieuw te gaan studeren. Ze wilde iets met haar talenpassie doen, maar haar diploma Engels uit Milaan gaf haar geen lesbevoegdheid. Daarom schreef zich aan de Universiteit van Amsterdam in voor Algemene Taalkunde. Ze koos die richting - en niet Italiaanse taal en letteren - ook omdat ze terecht hoopte te komen in het tweede-taalonderwijs voor immigrantenkinderen.

Jaren later, op 21 januari 2007, blikte ze tijdens een alumnidag aan de UvA terug op het parcours dat ze sindsdien had afgelegd: 'Als Italiaanse twintiger had ik nooit gedacht dat ik aan de UvA zou studeren, laat staan dat ik er ook nog zou doceren. Al vrij snel na het begin van mijn studie kreeg ik namelijk een baan aangeboden bij de vakgroep Italiaans, die een native speaker zocht. Ik werd belast met de colleges Italiaanse grammatica en vertaling. Ik had geen Italiaans gestudeerd en moest thuis keihard blokken. Na mijn afstuderen ben ik docente gebleven aan de UvA tot ik toe was aan iets anders.'

Dat andere werd uiteindelijk een uitgeverij: een wereld die haar niet geheel vreemd was, aangezien haar moeder in eigen beheer een paar boeken over hun familiegeschiedenis gepubliceerd had en haar zus een kleine uitgeverij van kunstboeken leidde in Venetië. Terwijl ze nog tot 1999 aan de universiteit bleef werken, ging ze in 1997 van start met Serena Libri. Ze was toen 57, een leeftijd waarop vele anderen besluiten het wat rustiger aan te gaan doen. Als logo, dat op de ruggen van al haar boeken staat, koos ze een bijzonder diertje: 'Een stokstaartje is het. Ik zag ze op safari in Afrika. Daar stonden ze met nieuwsgierige ogen brutaal om zich heen te kijken. Ze zijn in staat om een slang aan te vallen en te doden.' Die vitaliteit, dat is Anna ten voeten uit. En die zelfverzekerdheid: 'Ik heb weinig te vrezen van grote uitgeverijen. Er is wel eens een auteur overgestapt, maar dat beschouw ik als een eer.'

Dit laatste is cum grano salis te nemen: in privégesprekken kon ze best bitter zijn als ze het had over auteurs die zij in het Nederlands had gelanceerd en die door kapitaalkrachtiger concurrenten werden 'weggekocht'. Het meest tot de verbeelding spreekt natuurlijk het geval van haar best verkopende schrijver, Andrea Camilleri, die door Prometheus werd overgenomen. Een succes bleek die zet overigens niet, want na vier titels hield Prometheus het voor gezien en kon zij weer doorgaan met haar Montalbano-reeks.

In het kantoor op de begane grond van haar herenhuis in de Vossiusstraat, met zicht op het Vondelpark, runde Anna drieëntwintig jaar lang met onuitputtelijke energie haar unieke eenvrouwszaak. Niet alleen vanuit dat kantoortje trouwens, want zij was een echte globetrotter. In de mezzanine die als logeerkamer dienstdeed, stond een indrukwekkende batterij reisgidsen over alle werelddelen, en ik zal zeker niet de enige vertaler geweest zijn die van haar een e-mail of zelfs een telefoontje met een vraag of een instructie kreeg uit Buenos Aires of Mauritius. Waar ze ook ging, ze nam haar uitgeverij overal met zich mee. In 2003 kwam daar ook nog 'Het tuinhuis van Serena Libri' bij: een trefpunt dat ze liet bouwen in haar riante tuin, waar boekpresentaties en ontmoetingen met Italiaanse auteurs konden plaatsvinden. Ik schreef dan wel 'eenvrouwszaak', en dat was het ook, maar in feite draaiden er altijd enkele tientallen mensen - van proeflezers tot persklaarmakers - om haar heen, die zij met haar bijzondere uitstraling allemaal in de door haar gewenste richting wist te dirigeren: je kon gewoon geen nee tegen haar zeggen. Als er in haar tuinhuis een presentatie was, stonden er altijd wel een paar Italiëminnende dames klaar om een halve dag lang hapjes te bereiden. Daar stond altijd een grote generositeit tegenover: meer dan één vertaler heeft een weekje gratis in een van haar vakantiehuizen in Italië kunnen doorbrengen ('weet je, het staat daar al eventjes leeg, je zou me een dienst bewijzen als je het daar eens gaat verluchten...'). 
Nu dit avontuur door haar overlijden helaas is afgesloten ('We hebben in overleg met Annaserena besloten geen nieuwe boeken meer uit te brengen,' melden haar nabestaanden op de website van de uitgeverij) kunnen we in haar fonds een drietal krachtlijnen onderscheiden. Er zitten boeken bij van intussen klassiek geworden twintigste-eeuwse Italiaanse auteurs die in Anna's ogen in Nederland tot dan toe verwaarloosd waren (Carlo Emilio Gadda, Renata Viganò, Corrado Alvaro, Domenico Rea, Beppe Fenoglio en vooral Leonardo Sciascia, wiens oeuvre ze bijna integraal uitbracht of heruitbracht) of van wie sommige werken nog in het Nederlands ontbraken (het debuut van Italo Calvino, een vergeten novelle van Italo Svevo). Een tweede lijn is die van Italiaanse prozaïsten die na de Tweede Wereldoorlog geboren zijn en niet of nauwelijks door het Nederlandse publiek ontdekt waren (Marco Lodoli, Alessandro Perissinotto, Marta Morazzoni...). Een derde reeks - met een eigen vormgeving - is die van de Italiaanse giallisti, die hier te lande zo goed als onbekend waren (Camilleri natuurlijk, maar ook klassiekers als Piero Chiara en Giorgio Scerbanenco en recentere detectiveschrijvers als Francesco Recami). Wat de 92 boeken die ze uiteindelijk publiceerde gemeen hebben, is dat zij ze zelf de moeite waard vond. Serena Libri was dan ook geen commerciële onderneming, maar het product van een persoonlijke passie. Vermoedelijk heeft zij heel wat van haar eigen vermogen in haar droomproject geïnvesteerd.

Als een duivel-doet-al begeleidde ze elke ontstaansfase van haar boeken - van de vertaling over de vormgeving tot de marketing - en dat deed ze met een niet aflatend perfectionisme (de 'moeilijke Anna' uit haar overlijdensbericht). Alle vertalingen vergeleek ze zin per zin met het origineel, en ik heb het meegemaakt dat we nog na middernacht via Skype zaten te discussiëren over de interpretatie van een bepaalde passage. Niet alle vertalers vonden deze 'bemoeizucht' even plezierig, mij zelf gaf het een comfortabel gevoel. In elk geval heeft ze heel wat debutanten - in het begin vaak oud-studenten van haar - een kans geboden om zich in de wereld van de literaire vertaling te lanceren.

Haar apostolaatswerk ten bate van de Italiaanse cultuur beperkte zich overigens niet tot de taal en de literatuur. Ook de authentieke (Noord-)Italiaanse keuken wilde ze uitdragen, en dat deed ze niet alleen voor haar gasten aan haar fornuis. Zo publiceerde ze in 1983 samen met haar dochter Italiaanse menu's voor de wintermaanden en zijn er her en der op het internet nog méér recepten van haar hand terug te vinden. Ooit had ze zelfs getwijfeld tussen de oprichting van een restaurant en van een uitgeverij, en het argument dat uiteindelijk de doorslag gaf, was dat het makkelijker is in je eentje een uitgeverij dan een restaurant draaiend te houden.

'Werk dat nooit verloren zal gaan,' luidt Anna's laatste hartenkreet. Het beeld van de Italiaanse literatuur in het Nederlandse taalgebied zal inderdaad nooit meer hetzelfde zijn. Terwijl de grote literaire uitgeverijen zich richten op wat de internationale agentschappen en de Frankfurter Buchmesse als potentiële bestsellers aanbieden, wist Serena Libri via informanten en persoonlijke contacten een andere ader aan te boren. Daarzonder zouden sommige schrijvers nooit in het Nederlands zijn vertaald.

Toen ze nog aarzelde over het stichten van een uitgeverij, nam ze via haar zus contact op met een Italiaanse uitgever. 'Doe het niet,' zei die, 'tenzij je geld wilt verliezen.' Ze heeft het gedaan, eigenzinnig zoals ze altijd is geweest. Met haar overlijden en met het einde van haar uitgeverij verliest Italië een veelzijdige ambassadrice, de Nederlandse cultuur een blikopener op Italië en haar vrienden en kennissen een buitengewoon hartelijke en gastvrije vrouw. ${ }^{1}$

\footnotetext{
${ }^{1}$ Met dank aan Sophie Jitta, Jessica de Jong, Hilda Schraa, Yond Boeke en Tom de Keyzer. De citaten werden gesprokkeld uit diverse interviews die op het internet te vinden zijn.
} 
Frans Denissen is schrijver en vertaler van Italiaanse en Frans-Belgische literatuur. Zo vertaalde hij Boccaccio, Umberto Eco, Curzio Malaparte, Cesare Pavese, Leonardo Sciascia, Fleur Jaeggy. Zijn vertaling van Carlo Emilio Gadda's Die gore klerezooi in de Via Merulana (2000) werd bekroond met de Premio Biblioteca Europea. In 2012 ontving hij de Martinus Nijhoff Vertaalprijs, de belangrijkste onderscheiding voor vertalers in de lage landen.

frans.denissen@telenet.be 